\title{
KEY PERFORMANCE INDICATORS IN THE HOTEL INDUSTRY
}

\author{
Ljiljana Kosar', \\ Slobodan Rašeta², \\ Nikolina Kosar ${ }^{3}$ \\ ${ }^{1}$ The College of Hotel Management, \\ Belgrade, Serbia \\ ${ }^{2}$ QMS Consultant, \\ Belgrade, Serbia \\ ${ }^{3}$ The College of Tourism, \\ Belgrade, Serbia
}

\begin{abstract}
:
The initial assumption of successful business of the hotel company is orientation towards quality. The quality of a hotel product is a market category that can and should be measured. This requires identification of key performance indicators of hotel companies and ways of their measurement. The aim of this paper is to highlight the importance of performance for the quality management system, especially in the light of the new standards ISO 9001 from 2015, as well as to illustrate the performance measurement methods in the hotel industry. The heterogeneity of the hotel product imposes a flexible approach to determining the key performance indicators. Therefore, their specifics will be shown herein. It also highlights the problem of performance measurement and for this purpose, introduces and explains the notion of comparative value, which represents the projected standard, established on the basis of the expected quality. Thus, in the context of observation and measurement of the key performance indicators, quality in hotel industry is considered a dynamic and measurable category.
\end{abstract}

Keywords:

indicator, performance, measurement, quality, hotel industry.

\section{INTRODUCTION}

The hotel product quality approach is based on identification of processes that are crucial for its implementation. Thereby, it is necessary to differentiate between processes themselves and their performance. This distinction allows for the measurement of process performance, thus evaluating the quality of the hotel product.

It is necessary to demonstrate the compliance between the planned and actual process performance by measurable indicators, in order to determine the degree of implementation of the expected quality. Thereby, it should also be mentioned that the planned process performance is based on the expectations of consumers - hotel guests. The planned process performance, based on a realistic assessment of consumer needs, is the starting point of the hotel product quality. The level of compliance between the consumer expectations, which contain their requirements, needs, desires, and experiences attained through immediate consumption, expresses the actual level of the achieved quality of the hotel product.
Correspondence:

Ljiljana Kosar

e-mail:

ljiljana.kosar@gmail.com 
THE SPECIFICS OF THE PROCESS PERFORMANCE IN THE HOTEL INDUSTRY

Every organization has its business processes, business rules and decisions, regardless of whether they are identified or not and whether the members of the organization are aware of them or not (Smith, 2003). The identification of processes is preceded by their definition. Most definitions are based on the literature on the re-engineering of business processes created in the 1990s. One common definition of business processes is as follows: The process is a structured, measurable set of activities designed for the production of a specific output for a particular customer or market. In other words, the process is a specific sequence of work activities in time and space, with its beginning and end, i.e. with defined inputs and outputs, that is, the structure of the operation (Davenport, 1995). The business process can be more closely defined as a structured, analytical interfunctional set of activities that require constant improvements. These activities have a clearly defined beginning and end, during which, in a more or less constant intervals, a value for consumers is created (BosiljVuksic et al., 2008).

In the hotel industry, from the point of process identification, one can access a unique complex process, consisting of a series of interrelated processes, sub-processes, and support processes, whose occurrence is caused by the presence of guests in the hotel. This unique, complex process is referred to as a guest cycle that takes place in three main phases: arrival, stay and departure. At each stage, one can identify the basic processes, sub-processes, and support processes, which define the provision of accommodation and food to hotel guests. During the consumption of the hotel product, guests consume its various components and express a lower or higher degree of satisfaction. On the other hand, during the stay of guests in the hotel, particular services are successively repeated. This often leads to inconsistencies in the quality of delivered services, leading to variable customer satisfaction.

These specifics of the guest cycle in the hotel lead to the need for determining the performance of all processes involved in the implementation of the hotel product, with the aim of establishing the desired degree of compliance with consumer requirements, that is, the appropriate level of quality.

In the context of highlighting the importance of innovation for entrepreneurship, Peter Drucker discusses innovative performance, pointing out that they are achievements by means of innovation (Drucker, 1996).
Performance is considered to be the end result of an activity. Assuming that this activity takes place by performing business responsibilities in the most efficient and effective way, the expected effect is the result of the performed activity. The process performance, therefore, can be defined as the effect of the given process, in which measuring takes place (Raseta, 2007). Unlike the performance of individual activities, organizational performance is particularly important for quality management. Organizational performance implies the accumulated end result of all organizational and work processes and activities (Robins \& Coutler, 2005).

\section{KEY PERFORMANCE INDICATORS IN THE HOTEL INDUSTRY}

Each organization focused on quality has to measure the performance of their processes. The initial step in accomplishing this task is to determine the key performance indicators (KPI). They are measurable indicators that evaluate the business success of the organization as a whole or some of its parts.

Key performance indicators include a set of value indicators of business activities that are subject to measurement. They can be systematized as follows (MESA Metrics Research Study, 2012):

- Quantitative indicators that can be presented numerically,

- Qualitative indicators that cannot be presented numerically,

- Leading indicators that can predict the outcome of the process,

- Lagging indicators of realized business success or failure,

- Input indicators that measure the amount of resources involved in the reproduction process,

- Process indicators that represent process efficiency,

- Output indicators that reflect the outcomes of processes and activities,

- Practical indicators that are used for comparison with other processes in the organization,

- Directional indicators that indicate the progress, stagnation or decline of the organization in some sectors,

- Effective indicators that initiate changes,

- Financial indicators that are used in the measurement of efficiency. 
An organization that measures the performance of its processes should focus on several key indicators that will best reflect its business priorities. As business priorities change, key performance indicators should also change. The so-called SMART model can serve for the selection of the most appropriate indicators (Meyer, 2003). The model name is an abbreviation of the initial letters of the five key criteria (S-specific, M-measurable, A-attainable, R-relevant, T-time-bound).

The first criterion (S) requires setting a clear and an unambiguous objective, not the general one. The concretization of the objective is achieved by answering the five key questions, that is, by using the model $5 \mathrm{~W}$ :

- What - What do I want to accomplish?;

- Why - Why, what are the benefits of this accomplishment?;

- Who - Who is involved in the execution of this task?;

- Where - Where will the work take place - the location identification?;

- Which - Which is the work - the identification of conditions and restrictions?

The second criterion (M) insists on the measurability of the objective. Without measurability, it is not possible to monitor the progress in activities to achieve the objectives. The measurability of objectives is provided by answering the questions: How much? How do we know if the objective is being achieved? The third criterion (A) points out that the objectives have to be realistic and achievable. Setting achievable objectives implies identifying the ways to achieve them, that is, the provision of adequate resources (human, material, and financial). Thus, the fulfillment of the third criterion is the answer to the question: How can one achieve the objective? The fourth criterion (R) insists on the choice of truly important objectives, whose achievement has a significant impact on the improvement of the quality of a particular product or service, and therefore, on the success of the business activities of the organization. Important objectives are understood and supported by all levels of management in the organization, and also the direct executors, which creates a favorable business climate for their implementation. By identifying an important objective, positive answers to the following questions are provided:

- Is this project viable?

- Is this the right time for its implementation?

- Is it in accordance with the efforts and needs of the organization or its sector?

- Has the right team been selected for the project implementation?
- Is the project implementation feasible under the existing socio-economic and technical and technological circumstances?

The fifth criterion $(\mathrm{T})$ insists on setting time frames for the implementation of objectives and tasks.

Scheduling allows one to establish the optimal temporal dynamics and focus efforts towards intensifying activities and compliance with the deadline. Time-bound objectives should provide answers to the following questions:

- When?

- What can I do in the next six months?

- What can I do in the next six weeks?

- What can I do today?

Bearing in mind the heterogeneity of the hotel product quality, it is necessary to access the selection of key performance indicators very carefully and selectively. In the hotel industry, quantitative and financial indicators are most commonly used. Quantitative indicators include the number of tourists and overnight stays in a hotel, the percentage of accommodation capacity utilization, the number of produced and served meals, while the financial indicators are mostly focused on the relationship between income and expenses, including the structure by sectors, that is, types of services (accommodation, food and beverages, other). Revenue per available room (RevPAR) is an important financial indicator. This is a complex indicator that reflects the economic efficiency of business activities of the entire hotel. An objective of hotel management, especially the one with the pronounced seasonal business, is to have the average revenue per available room as high as possible. However, the increase in the percentage of utilization of hotel capacities does not always lead to a proportional increase in revenue per available room. Digressive increase, or even stagnation, represents the result of lower selling prices in the preseason and postseason. This leads to an increase in capacity utilization, but not necessarily to an increase in additional spending. In recent years, revenue per occupied room (RevPOR) has been introduced as an indicator of performance, which more clearly indicates the level of hotel guests' spending (Mogelonsky, 2013). In this sense, business activities can be focused on increasing the spending of the existing guests by introducing additional contents and permanent quality improvement.

The hotel guest satisfaction is treated as a specific key indicator of performance. In accordance with the above-mentioned classification, it is an output indicator of a qualitative nature. The final outcome of the process of implementation of a hotel product is a hotel guest 
with his/her experience, consistent with the preformed expectations to a greater or lesser extent. If performance is understood as a functional capability of a process (Kukoleca, 1985), then the cumulative result of the functional capability of the hotel product implementation process is consumer satisfaction. Although it is an indicator of a qualitative nature, based on the consumer behavior, modern managerial techniques, along with the help of information technology, that is, specialized software packages, enable permanent monitoring and measuring of hotel guest satisfaction.

\section{MEASURING CONSUMER SATISFACTION IN THE HOTEL INDUSTRY}

The effect of a process can be measured using the performance index. The performance index is the ratio of the measurement of the output values and the planned (expected) values of a process. Considering the above-given, it follows that the performance index is a numerical value of effectiveness and efficiency, that is, a measure of effectiveness and efficiency (Raseta, op. cit.). Effectiveness is the degree of implementation of the planned activities and planned results (ISO op. cit.). Efficiency is the ratio of the results achieved and resources used (ISO op. cit.). Contemporary models for the process performance measurement insist on compliance with different priorities, depending on the position in the management hierarchy. In order to achieve the key purpose of measurements, it is necessary to establish the appropriate performance measurement system (PMS). The balanced scorecard (BSC) concept, which aims to provide managers with the most important information on the activities they manage, is widely used (Kaplan \& Norton, 1996). The insistence of the BSC model on clarity and usefulness is reflected in the selective approach to indicators that are subject to measurement, that is, in filtering and clustering as key activities.

The performance prism represents a more complex, more comprehensive and more contemporary model for performance measurement. The initial assumption of the performance prism is to create values for the key stakeholders. They are considered to be investors (shareholders), customers (consumers), employees, suppliers, strategic partners, and the community. The performance prism is an integral model for measuring the performance of five dimensions (Neely et al., 2002). Stakeholder satisfaction is the upper plane of the prism. The contribution of stakeholders to the organization is the lower plane (the bottom) of the prism. They are connected by three sides - strategies, processes and resources (skills).
According to this model, the appropriate tools and techniques should be provided to measure:

- stakeholder satisfaction,

- stakeholder contributions,

- success of the strategy toward a specific stakeholder group,

- performance of the processes that are key for the strategy implementation,

- performance of the resources that are required for taking place of the process of implementation of a particular strategy.

The measurement of process performance in the hotel industry is shown by measuring customer satisfaction. The measurement of process performance implies transparency, i.e. regular screening and interpretation of measurement results to all employees.

The hotel guest should be in the spotlight for the stakeholders. The satisfaction of other stakeholders is reflected through hotel guest's satisfaction. The roots of the guest's dissatisfaction with particular components of the hotel product should be sought in the dissatisfaction of employees, suppliers, other strategic partners, which is, in turn, a result of noncompliance with objectives, strategies, processes, and performance. Therefore, the first step towards implementation of more comprehensive models for measuring the process performance in the hotel industry is a continuous measurement of customer satisfaction. The guest survey, nowadays, via electronic questionnaires, is the most common way of measuring customer satisfaction. The SERVQUAL model, based on the degree of compliance between the expected and the perceived quality, is also applied. This model basically includes five groups of components (according to: Parasuraman et al., 1988, taken from: Kosar \& Đurišić, 2010):

- tangible components of service quality;

- reliability - the ability to realize the service in the agreed manner and at the agreed time;

- responsibility - professionalism, the awareness of the importance of the service for the customer;

- trust - expertise, the ability to gain the service user's trust;

- empathy (compassion) - understanding, the ability to put oneself into the position of the user, an individualized approach to the service user.

Service users are interviewed twice, in the pre-consumption stage, when their expectations are measured, and in the post-consumption stage, when the quality of perception is measured. The quality of services is determined on the basis of the comparison between 
expectations and perceptions, by measuring deviations, i.e. noncompliance for each criterion, a group of criteria, and the hotel itself. On the other hand, the double survey might be an additional burden for customers. For this reason, SERVPERF, a model that measures only service performance (service performance SERVPERF), i.e. the perceived quality, has been created (according to: Cronin \& Taylor, 1994, taken from: Kosar \& Đurišić, 2010).

The American Customer Satisfaction Index (ACSI) is among the best known techniques of objective measurement of satisfaction (according to: Gerson, 1994, taken from: Kosar \& Đurišić, 2010). ACSI model determines the degree of customer satisfaction based on a specific methodology, on the basis of measuring consumer expectations, the perceived (obtained) quality, and the perceived (obtained) value.

ECSI is the European Customer Satisfaction Index, which takes into account individuality in the behavior of European consumers. Depending on the influence of ethno-sociological, socio-economic and physicalgeographical factors, many countries have developed their own methodologies for calculating the consumer satisfaction index.

Continuous monitoring of customer satisfaction index is a regular activity of international hotel companies, i.e. corporate chains. For instance, specialized companies engaging in consumer satisfaction in the USA and Canada carry out annual research and publish the index of hotel guest satisfaction in selected hotels in North America. In July 2016, “J.D. Power" company published, the latest research on this topic (J.D. Power, 2016). The survey was conducted between July 2015 and May 2016 and included more than 63,000 guests from the United States and Canada, who stayed in the selected hotels in North America. The survey, which has been conducted for 20 years, included eight types of objects - luxury, upper upscale, upscale, midscale, economy/budget, upper extended stay and extended stay. Seven key factors of the hotel product quality have been selected for the purpose of evaluation: booking, check-in/check-out activities, hotel rooms, food and beverage, hotel services, other hotel amenities, prices and other fees. According to this research in 2016, the total index of hotel guest satisfaction was 808 on the scale of 1000 , which is by 2 index points higher compared to the results in the previous year. Research has shown a higher degree of satisfaction of the guests who are members of reward programs by hotel brands.

The inclination to membership in these programs is lower fot younger guests. The guests who booked a hotel via the Internet or a phone application express a higher level of satisfaction with this service than others. According to this research, the most important amenities for guests include free wireless internet, breakfast (assortment, quality of service), free parking, and bedding quality. Research has also shown that feedback on social networks is mainly given by satisfied guests. The total satisfaction is by 40 index points higher for the guests who have sent posts on social networks.

According to the research of "J.D. Power" company, consumer satisfaction for the previous three-year period is presented in the following table.

Table 1. J.D. Power North America Hotel Guest Satisfaction Index

\begin{tabular}{lccc}
\hline \multirow{1}{*}{ Hotel brand } & \multicolumn{3}{c}{ Study Year } \\
\cline { 2 - 4 } & 2014 & 2015 & 2016 \\
\hline $\begin{array}{l}\text { Luxury Segment } \\
\text { Average }\end{array}$ & 849 & 857 & 869 \\
\hline $\begin{array}{l}\text { Upper Upscale Seg- } \\
\text { ment Average }\end{array}$ & 819 & 837 & 838 \\
\hline $\begin{array}{l}\text { Upscale Segment } \\
\text { Average }\end{array}$ & 815 & 833 & 833 \\
\hline $\begin{array}{l}\text { Upper Midscale Seg- } \\
\text { ment Average }\end{array}$ & - & 822 & 824 \\
\hline $\begin{array}{l}\text { Midscale Segment } \\
\text { Average }\end{array}$ & 801 & 787 & 792 \\
\hline $\begin{array}{l}\text { Economy/Budget } \\
\text { Segment Average }\end{array}$ & 697 & 728 & 727 \\
\hline $\begin{array}{l}\text { Extended Stay Seg- } \\
\text { ment Average }\end{array}$ & 752 & - & \\
\hline $\begin{array}{l}\text { Segment Average } \\
\text { Evy }\end{array}$ & 836 & 852 & 844 \\
\hline
\end{tabular}

Source: J.D. Power North America Hotel Guest Satisfaction Index Study, 2014, 2015, 2016

* Empty cells are the result of changes in the methodology of classifying objects in 2014 and 2015.

All presented class brands have a positive trend of satisfaction, except for the economic/budget segment. It is perceived that the lower the brand category is, the lower the satisfaction index is. Thus, luxury brands have the highest, and economic/budget brands have the lowest 
satisfaction index. This phenomenon can be explained by high expectations of consumers that do not decrease proportionately with the brand category. On the other hand, lower-class brands should be more involved in raising the quality of their services.

Consumer satisfaction is a complex indicator of process performance. The higher the satisfaction indicators are, the higher the process performance is. Customer satisfaction integrates all other indicators of performance in the hotel industry. Satisfied customers contribute to increasing loyalty that initiates a higher degree of utilization of accommodation and other facilities, higher average spending, i.e. higher RevPAR. Thus, customer satisfaction management represents the basis of the performance measurement process in the hotel industry.

\section{PROCESS PERFORMANCE MANAGEMENT IN THE HOTEL INDUSTRY}

According to ISO 9001 standards, a quality management system is committed to the process identification and management, as well as process performance measurement. A performance management system should be treated as a subsystem of the quality management system. The structure of a performance management system is shown in Figure 1.

The effectiveness and efficiency of the performance management system are based on the operation of four groups of activities, as presented in Figure 1. The basis for measurements is identification of performance standards. International hotel chains base their business success and globally recognizable image on a complex orientation towards quality. Corporate quality standards are built on the basis of the process approach and standardization of performance of the previously identified key processes. In the next phase of performance management system, measurement activities are undertaken. The techniques and methods of performance measurement are constantly improving. International hotel chains make partnerships with the leading world companies engaged in the production of computer programs for process performance measurement, based on the application of statistical and mathematical models. In this area, the domain of monitoring customer satisfaction, where advanced mobile technologies are being included, is the most progressive. The next phase of performance management system includes ongoing reporting activities. The aim of these activities is to achieve full work transparency, which is also realized with the help of software packages and mobile technology. The process of quality improvement is the main purpose of the performance management system. Managerially established, the previous three groups of activities lead to the quality improvement of the hotel product. An improvement in quality requires further improvement of performance standards, customization of the measurement system, new analyses of the results and information, and thus, a new cycle of quality improvement. Therefore, performance management is a dynamic system that operates cyclically, constantly following the changes in the internal and external environment. International hotel chains make changes in their performance management systems through re-branding, thus creating new services. In this way, they reposition themselves on the market, become more attractive partners in the field of franchising and management business, and achieve greater share in the global market.

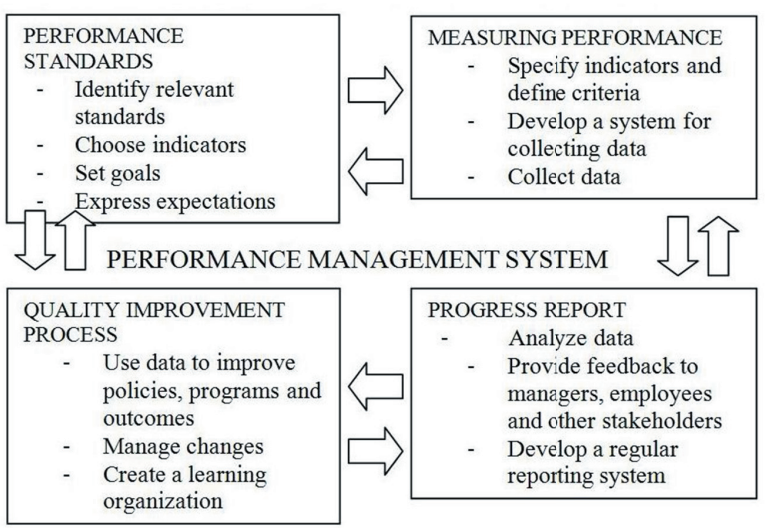

Figure 1. The structure of a Performance Management System

Source: Kosar \& Raseta (2013, p. 157)

In the hotel management practice, process performance is ultimately reduced to the effect of human labor. Permanent exposure to checks can adversely affect employees in the hotel industry and increase their vulnerability to stress. To that end, it is necessary to take the following concrete steps to ensure the effectiveness and efficiency of the performance management system:

- develop clear processes and mechanisms for performance monitoring, which are understood by employees;

- file processes and regularly keep records of meetings and other forms of communication with employees;

- set clear, realistic and achievable expectations for employees;

- discuss with employees the issues related to the achievement of the required standards and the plan to improve performance; 
- give some time to employees to improve their performance, especially when overcoming of bad habits is necessary;

- focus on the employee progress, not on the mistakes they have made;

- provide adequate and timely training and support along the way to improve performance by enhancing employee skills;

- provide feedback to employees on the pace of their progress.

\section{CONCLUSION}

The contemporary approach to quality management focuses on the processes, i.e. their performance. Performance management requires previous identification of processes, properly selected key performance indicators, appropriate measurement methods, expert analysis of the results and activities of new improvements. Process performance management, which provides continuous functioning of the quality cycle, is particularly important for services, in this case, the hotel industry. Consuming a hotel product is achieved through implementation of the guest cycle. The guest cycle includes a series of interrelated and interconnected processes, i.e. services provided to guests from the moment of booking, through their arrival and stay, until leaving the facility. The total quality of the hotel product ensures the compliance with the quality cycle (process performance management) and the guest cycle.

The absence of a compact material form, heterogeneity, intangibility, consumer inversion, changeability in requirements, needs, and desires of users, and an individualized operation mode, objectively hinder process performance management in the hotel industry. Investments in modern organizational structures, employee trainings, models for monitoring, measurement and analysis of the process performance are the profitable investment for the future.

\section{REFERENCES}

Bosilj-Vukšić, V., Hernaus, T., \& Kovačič, A. (2008). Upravljanje poslovnim procesima: organizacijski $i$ informacijski pristup. Zagreb: Školska knjiga.

Davenport, T.H. (1995). Reengrneenng a Business Process. Boston: Harvard Business School Press.
Drucker, P.F. (1996). Inovacije i preduzetništvo: Praksa $i$ principi. Beograd: Grmeč.

Harrington, J.H. (1991). Business Process Improvement. New York: McCraw-Hill.

J.D. Power. (2016). North America Hotel Guest Satisfaction Index Study 2016. Retreived September 3, 2016 from http://www.jdpower.com/resource/jd-powernorth-america-hotel-guest-satisfaction-index-study

Kaplan, R., \& Norton, D. (1996). The Balanced ScorecardTranslating Strategy into Action. Boston: Harvard Business School Press.

Kosar, Lj., \& Rašeta, S. (2005). Izazovi kvaliteta. Belgrade: Viša hotelijerska škola.

Kosar, Lj. (2009). Uticaj zadovoljstva zaposlenih na kvalitet usluga u hotelijerstvu. HOTELLINK 13-14/2009, 931936

Kosar, Lj., \& Đurišić, B. (2010). Menadžment kvaliteta u hotelijerstvu. Belgrade: Viša hotelijerska škola.

Kosar, Lj., \& Rašeta, S. (2013). Performanse procesa kao ključni činilac kvaliteta hotelskog proizvoda. Hotelska kuća 2013. Zlatibor, 145-160.

Kukoleča, S. (1986). Organizaciono-poslovni leksikon. Belgrade: Rad.

Meyer, P. J. (2003). What would you do if you knew you couldn't fail? Creating S.M.A.R.T. Goals. Retreived September 3, 2016 from https://www.qualistar.org/ uploads/file/smartgoals.pdf

Mogelonski, L. (2013). RevPar vs. RevPor. Retreived September 3, 2016 from: www.hotelsmag.com/Industry/ Blogs/Details/44361\#sthash.uLFtZ2DB.dpuf.

Neely, A., Adams, C., \& Kennerley, M. (2002). The Performance Prism: The Scorecard for Measuring and Managing Business Success. London: Prentice Hall.

Pace Today. (2011). Pursuit of Performance Excellence: Business Success through Effective Plant Operations Metrics. Retreived September 3, 2016 from https:// pacetoday.com.au/pursuit-of-performance-excellence-business-success-through-effective-plant-operations-metrics/

Rašeta, S. (2007). Merljivi ciljevi i merenje performansi u uslugama. Zbornik radova XVII konferencije o kvalitetu, Kvalitet - domaća praksa i svetska iskust$v a$. Beograd: Jugoinspekt.

Rentzhog, O. (1998). Processartentering: En Grund for Nlorgondagerts Organisattoner. Lund: Studentlineratur.

Robins, S.P., \& Coutler, M.(2005). Menadžment. Beograd: Data status.

Smith, S. (2003). Strateg: Kako poslovni cilj pretvoriti u uspjeh. Zagreb: M.E.P. Consult. 